Original Scientific Article

\title{
ISOLATION RATE OF CAMPYLOBACTER SPP. AND DETECTION OF VIRULENCE GENES OF CAMPYLOBACTER JEJUNI ACROSS THE BROILER CHAIN
}

\author{
Ljupco Angelovski, Zagorka Popova, Katerina Blagoevska, Sandra Mojsova, \\ Marija Ratkova Manovska, Mirko Prodanov, Dean Jankuloski, Pavle Sekulovski \\ Faculty of Veterinary Medicine - Skopje, Ss. Cyril and Methodius University in Skopje, \\ Lazar Pop Trajkov 5-7, 1000 Skopje, R. North Macedonia
}

Received 16 March 2021; Received in revised form 10 May 2021; Accepted 17 May 2021

\begin{abstract}
The aim of the study was to identify the isolation rate of thermotolerant campylobacters in a small-scale broiler-meat production farm over a one-year period. The second deliverable of the study was to determine the potential virulence markers. The laboratory investigation was performed on 283 samples (cloacal swabs, caeca, carcass swabs) collected on three sampling points (farm, slaughter line, and cold storage). The isolates obtained with the conventional microbiological method were confirmed with multiplex PCR for identification of campylobacters. The presence of 10 virulence genes was analyzed in the C. jejuni isolates (flaA, racR, virB11, dnaJ, wlaN, cadF, ciaB, cdtA, cdtB, cdtC). Out of 283 samples, 169 (59.7\%) were confirmed as Campylobacter spp., 111 (39.2\%) C. jejuni, and $43(15.2 \%)$ C. coli. C. jejuni was the most prevalent in all sampling points. Campylobacter spp. showed a characteristically seasonal prevalence with the highest isolation rate during the warmer period of the year. We detected the $c a d F$ and $c i a B$ genes in all $C$. jejuni isolates. The flaA gene was present in $50 \%$ of the examined strains. The $c d t$ genes $(c d t A, c d t B$, and $c d t C$ ) were confirmed in $52.8 \%, 52.8 \%$, and $47.2 \%$ of the C. jejuni strains, respectively. C. jejuni showed 15 profiles of virulence patterns with four predominant profiles.
\end{abstract}

Key words: isolation rate, Campylobacter spp., virulence, Campylobacter jejuni, broiler chain

\section{INTRODUCTION}

The genus Campylobacter contains 31 species, 11 subspecies, and 3 biovars. Some of them are of high significance for the human and animal health (1). In $90 \%$ of the human infections, $C$. jejuni and C. coli were isolated in the stool samples $(2,3)$. It is estimated that $80-90 \%$ of poultry flocks are mainly colonized with $C$. jejuni and C. coli, and infrequently with C. lari and C. upsaliensis (4).

Campylobacter is the most commonly reported causative agent for human bacterial diarrhoeal disease in the European Union since 2005 (5). The

Corresponding author: Ljupco Angelovski, DVM, MSc

E-mail address: angelovski@fvm.ukim.edu.mk

Present address: Faculty of Veterinary Medicine - Skopje,

Ss. Cyril and Methodius University in Skopje, Lazar Pop Trajkov 5-7,

1000 Skopje, R. North Macedonia

Phone: +38923240787

Copyright: (C) 2021 Angelovski Lj. This is an open-access article published under the terms of the Creative Commons Attribution License which permits unrestricted use, distribution, and reproduction in any medium, provided the original author and source are credited. Competing Interests: The authors have declared that no competing interests exist.

Available Online First: 19 June 202

Published on: 15 October 2021

https://doi.org/10.2478/macvetrev-2021-0020 main source of infection is by consumption of food with animal origin, especially undercooked poultry meat, unpasteurized milk, or cross-contaminated meat products during preparation and storage (6). Besides these risk factors there are several more that are worth considering: abroad traveling, exposure to animals, working in slaughterhouses, animal farms visiting, consumption of pork meat, contact with dogs and cats, and swimming in open waters $(7,8,9,10)$.

The infection is usually brief, mild, self-limiting, and generally does not require any treatment. In some cases, the infection is associated with serious clinical manifestations such as bacteremia, reactive arthritis, hemolytic uremic syndrome, meningitis, septicemia, and Guillain-Barré syndrome $(1,11)$. Macrolides and fluoroquinolones are frequently used as the first and second-choice drugs for highrisk patients (young, elderly, immunocompromised individuals) (12).

Many authors have confirmed the seasonal pattern variation in the occurrence rate of Campylobacter. The usual prevalence spikes take 
place during the warmer months of the year and are generally associated with the higher survival of Campylobacter in the habitat (13).

The molecular pathogenic mechanism in Campylobacter infection is still not perfectly understood (14). The extensive research on campylobacters has revealed numerous genes relevant for their virulence and pathogenicity (15): flaA, flhA, cadF, dnaJ, and racR (genes that are engaged in the stage of adherence and colonization); virB11, $\operatorname{ciaB}$, and iam (genes important for the invasiveness); $c d t A, c d t B$, and $c d t C$ (genes bound to the cytotoxic effect on the epithelial cells), and wlaN (linked with the synthesis of the lipooligosaccharides, resulting in Guillain-Barré Syndrome) (16).

The objectives of this study were to 1) estimate the isolation rate of thermotolerant Campylobacter in broilers sampled in farms and slaughterhouse; 2) identify (if present) the seasonal variation in Campylobacter prevalence; 3) detect the presence of virulence-related genes in Campylobacter jejuni isolates, and 4) evaluate the detected virulence patterns in Campylobacter jejuni isolates.

\section{MATERIAL AND METHODS}

\section{Collection of samples}

This study was conducted on one broiler farm and slaughterhouse in the Skopje region, N. Macedonia, in the period between March and December 2017. All procedures involving animals were in accordance with the ethical standards and international guidelines for the care and use of animals.

A total of 283 samples were collected. The farm had a capacity of 10.000 broilers with a conventional system. The usual rate of slaughtering was by several thinning cycles of 1.500 broilers per day.

Cloacal swabs were taken from randomly chosen broilers at the farm one week prior to slaughter $(n=64)$. The samples were placed in plastic tubes containing $5 \mathrm{~mL}$ of Preston broth.

Broiler caeca were collected at the slaughter line $(n=166)$ during the evisceration phase, and were packed in sterile plastic bags. Samples were collected randomly from at least 40 birds in each sample-collection cycle during the slaughtering process.

Swab samples from broiler carcasses $(n=53)$ were taken in the storage area before shipping to the consumers (cold chamber of the slaughterhouse) using sterile cotton swabs, which were placed in plastic tubes containing $5 \mathrm{~mL}$ of Preston broth. The samples were collected the following day after slaughtering, including at least 10 carcasses in each sample-collection cycle.

Samples were stored and transported to the laboratory at $4-8{ }^{\circ} \mathrm{C}$. The laboratory analysis was initiated 3-4 hours after sampling.

\section{Isolation and confirmation of Campylobacter spp.}

The isolation and identification of thermotolerant Campylobacter was performed according to the standard ISO 10272-1:2017 (17). The positive isolates were sub-cultured on mCCDA agar plates and stored in glycerol broth at $-80{ }^{\circ} \mathrm{C}$.

\section{Extraction of DNA and PCR analysis}

The DNA preparation for the Campylobacter isolates was performed by the boiling method. The procedure included suspension of the cultures in $0.5 \mathrm{~mL}$ of TE buffer, boiling at $95{ }^{\circ} \mathrm{C}$ for $10 \mathrm{~min}$, and centrifugation at $15.000 \mathrm{rpm}$ for 5 minutes. Acquired supernatants were kept at $-20{ }^{\circ} \mathrm{C}$ and used for both PCR methods.

The multiplex PCR for identification and differentiation of Campylobacter spp. was performed with adaptations according to the previously published study (18). This multiplex PCR could identify several Campylobacter species (C. jejuni subsp. jejuni; C. coli, C. lari, C. upsaliensis, and C.fetus subsp. fetus). The list of the used primers is shown in Table 1.

PCR amplifications were performed in a mixture $(25 \mu \mathrm{L})$ consisting of $12.5 \mu \mathrm{L}$ of $2 \times$ Platinum Multiplex PCR Master Mix (Applied Biosystems, UK), $2.5 \mu \mathrm{L}$ of template DNA, and $5 \mu \mathrm{L}$ of primer mix $(0.5 \mu \mathrm{M} C$. jejuni and C. lari primers; $1 \mu \mathrm{M} C$. coli and C. fetus primers, $2 \mu \mathrm{M} C$. upsaliensis primers; $0.25 \mu \mathrm{M}$ $23 \mathrm{~S}$ rRNA primer). Distilled water was added to make $25 \mu \mathrm{L}$. DNA amplification was carried out in a thermocycler (Techne, UK) using an initial denaturation step at $95{ }^{\circ} \mathrm{C}$ for $2 \mathrm{~min}$ followed by 35 cycles of amplification (denaturation at $95{ }^{\circ} \mathrm{C}$ for $30 \mathrm{sec}$, annealing at $59{ }^{\circ} \mathrm{C}$ for $45 \mathrm{sec}$, and extension at $72{ }^{\circ} \mathrm{C}$ for $45 \mathrm{sec}$.), ending with a final extension at $72{ }^{\circ} \mathrm{C}$ for $10 \mathrm{~min}$.

The multiplex PCR for detection of the virulence genes in the $C$. jejuni isolates was performed as proposed by Datta (19). The list of the used primers is shown in Table 2. 
Table 1. Primer sequences used in the multiplex PCR assay and the expected sizes of the products (18)

\begin{tabular}{|c|c|c|c|c|}
\hline Target gene & $\begin{array}{l}\text { Primer } \\
\text { name }\end{array}$ & Sequence (5'-3') & $\begin{array}{c}\text { Annealing } \\
\text { temperature }\left({ }^{\circ} \mathrm{C}\right)\end{array}$ & $\begin{array}{l}\text { Product } \\
\text { (bp) }\end{array}$ \\
\hline \multirow{2}{*}{ C. jejuni hipO } & CJF & ACTTCTTTATTGCTTGCTGC & \multirow{2}{*}{59} & \multirow{2}{*}{323} \\
\hline & CJR & GCCACAACAAGTAAAGAAGC & & \\
\hline \multirow{2}{*}{ C. coligly $A$} & $\mathrm{CCF}$ & GTAAAACCAAAGCTTATCGTG & \multirow{2}{*}{59} & \multirow{2}{*}{126} \\
\hline & CCR & TCCAGCAATGTGTGCAATG & & \\
\hline \multirow{2}{*}{ C. lari gly $A$} & CLF & TAGAGAGATAGCAAAAGAGA & \multirow{2}{*}{59} & \multirow{2}{*}{251} \\
\hline & CLR & TACACATAATAATCCCACCC & & \\
\hline \multirow{2}{*}{ C. upsaliensis glyA } & CUF & AATTGAAACTCTTGCTATCC & \multirow{2}{*}{59} & \multirow{2}{*}{204} \\
\hline & CUR & TCATACATTTTACCCGAGCT & & \\
\hline \multirow{2}{*}{ C. fetus sapB2 } & CFF & GCAAATATAAATGTAAGCGGAGAG & \multirow{2}{*}{59} & \multirow{2}{*}{435} \\
\hline & CFR & TGCAGCGGCCCCACCTAT & & \\
\hline \multirow{2}{*}{ C. jejuni $23 S$ rRNA } & $23 \mathrm{SF}$ & TATACCGGTAAGGAGTGCTGGAG & \multirow{2}{*}{59} & \multirow{2}{*}{650} \\
\hline & 23SR & ATCAATTAACCTTCGAGCACCG & & \\
\hline
\end{tabular}

Table 2. Primer sequences used in the multiplex PCR assay and the expected sizes of the products (19)

\begin{tabular}{|c|c|c|c|c|}
\hline Target gene & Primer & Sequence (5'-3') & $\begin{array}{c}\text { Annealing } \\
\text { temperature }\left({ }^{\circ} \mathrm{C}\right)\end{array}$ & $\begin{array}{l}\text { Product } \\
\text { (bp) }\end{array}$ \\
\hline \multirow{2}{*}{$f l a A$} & flaA664 & AATAAAAATGCTGATAAAACAGGTG & \multirow{2}{*}{53} & \multirow{2}{*}{855} \\
\hline & flaA1494 & TACCGAACCAATGTCTGCTCTGATT & & \\
\hline \multirow{2}{*}{$c a d F$} & cadF-F2B & TTGAAGGTAATTTAGATATG & \multirow{2}{*}{45} & \multirow{2}{*}{400} \\
\hline & cadF-R1B & CTAATACCTAAAGTTGAAAC & & \\
\hline \multirow{2}{*}{ rack } & racR-25 & GATGATCCTGACTTTG & \multirow{2}{*}{45} & \multirow{2}{*}{584} \\
\hline & racR-593 & TCTCCTATTTTTACCC & & \\
\hline \multirow{2}{*}{ dnaJ } & dnaJ-299 & AAGGCTTTGGCTCATC & \multirow{2}{*}{46} & \multirow{2}{*}{720} \\
\hline & dnaJ-1003 & CTTTTTGTTCATCGTT & & \\
\hline \multirow{2}{*}{ virB11 } & virB-232 & TCTTGTGAGTTGCCTTACCCCTTTT & \multirow{2}{*}{53} & \multirow{2}{*}{494} \\
\hline & virB-701 & CCTGCGTGTCCTGTGTTATTTACCC & & \\
\hline \multirow{2}{*}{$c i a B$} & ciaB-403 & TTTTTATCAGTCCTTA & \multirow{2}{*}{42} & \multirow{2}{*}{986} \\
\hline & ciaB-1373 & TTTCGGTATCATTAGC & & \\
\hline \multirow{2}{*}{$c d t A$} & DS-18 & CCTTGTGATGCAAGCAATC & \multirow{2}{*}{49} & \multirow{2}{*}{370} \\
\hline & DS-15 & ACACTCCATTTGCTTTCTG & & \\
\hline \multirow{2}{*}{$c d t B$} & cdtB-113 & CAGAAAGCAAATGGAGTGTT & \multirow{2}{*}{51} & \multirow{2}{*}{620} \\
\hline & cdtB-713 & AGCTAAAAGCGGTGGAGTAT & & \\
\hline \multirow{2}{*}{$c d t C$} & $\operatorname{cdtC}-192$ & CGATGAGTTAAAACAAAAAGATA & \multirow{2}{*}{47} & \multirow{2}{*}{182} \\
\hline & cdtC-351 & TTGGCATTATAGAAAATACAGTT & & \\
\hline \multirow{2}{*}{$w l a N$} & wlaN-DL39 & TTAAGAGCAAGATATGAAGGTG & \multirow{2}{*}{46} & \multirow{2}{*}{672} \\
\hline & wlaN-DL41 & CCATTTGAATTGATATTTTTG & & \\
\hline
\end{tabular}

For this protocol each multiplex PCR tube contained $25 \mu \mathrm{L}$ of mixture: $12.5 \mu \mathrm{L}$ Platinum Multiplex PCR Master Mix (Applied Biosystems, UK), $2.5 \mu \mathrm{L}$ of template DNA, $5 \mu \mathrm{L}$ of primer mix ( $0.5 \mu \mathrm{M}$ of the used primers), and $5 \mu \mathrm{L}$ of distilled water. Amplification was performed with initial denaturation step at $95{ }^{\circ} \mathrm{C}$ for 2 min followed by 35 cycles of amplification (denaturation at $94{ }^{\circ} \mathrm{C}$ for $1 \mathrm{~min}$, annealing at a temperature specific to the primer pair for $1 \mathrm{~min}$, and extension at $72{ }^{\circ} \mathrm{C}$ for $1 \mathrm{~min}$ ) and final extension at $72{ }^{\circ} \mathrm{C}$ for $10 \mathrm{~min}$.

\section{RESULTS}

Isolation rate of thermotolerant Campylobacter, C. jejuni, and C. coli at broiler farm and at the slaughterhouse

The results of the study indicated that Campylobacter spp. was present in all phases of the production. The distribution of campylobacters was highest in the cloacal swabs $(73.4 \%)$. The results of the laboratory examinations showed that $C$. jejuni was the most prevalent species on the farm and in the slaughterhouse (Table 3). 
Table 3. Isolation rate of Campylobacter spp. at the farm, at the slaughter line and at storage

\begin{tabular}{lccccccc}
\hline $\begin{array}{l}\text { Sampling } \\
\text { point }\end{array}$ & $\begin{array}{c}\text { Number of } \\
\text { samples }\end{array}$ & $\begin{array}{c}\text { Type of } \\
\text { sample }\end{array}$ & $\begin{array}{c}\text { Campylobacter } \\
\text { spp. }\end{array}$ & C. jejuni & C. coli & C. lari & C. upsaliensis \\
\hline Farm & 64 & $\begin{array}{c}\text { Cloacal } \\
\text { swab }\end{array}$ & $\begin{array}{c}47(73.4 \% ; \\
\text { CI } 62.6-84.2)\end{array}$ & $31(48.4 \%)$ & $13(20.3 \%)$ & $2(3.1 \%)$ & $1(1.5 \%)$ \\
Slaughter & 166 & Cecum & $\begin{array}{c}102(61.4 \% ; \\
\text { CI } 54.4-68.4)\end{array}$ & $68(40.9 \%)$ & $25(15.1 \%)$ & $6(3.6 \%)$ & $3(1.8 \%)$ \\
line & 53 & $\begin{array}{c}\text { Carcass } \\
\text { Swab }\end{array}$ & $\begin{array}{c}20(37.7 \% ; \\
\text { CI } 24.9-50.6)\end{array}$ & $12(22.6 \%)$ & $5(9.4 \%)$ & $1(1.9 \%)$ & $2(3.8 \%)$ \\
Storage & 283 & $/$ & $\begin{array}{c}169(59.7 \% ; \\
\text { CI } 54.1-65.3)\end{array}$ & $111(39.2 \%)$ & $43(15.2 \%)$ & $9(3.2 \%)$ & $6(2.1 \%)$ \\
TOTAL & \multirow{2}{*}{$28 \%$} & &
\end{tabular}

CI, confidence intervals with $95 \%$ confidence level

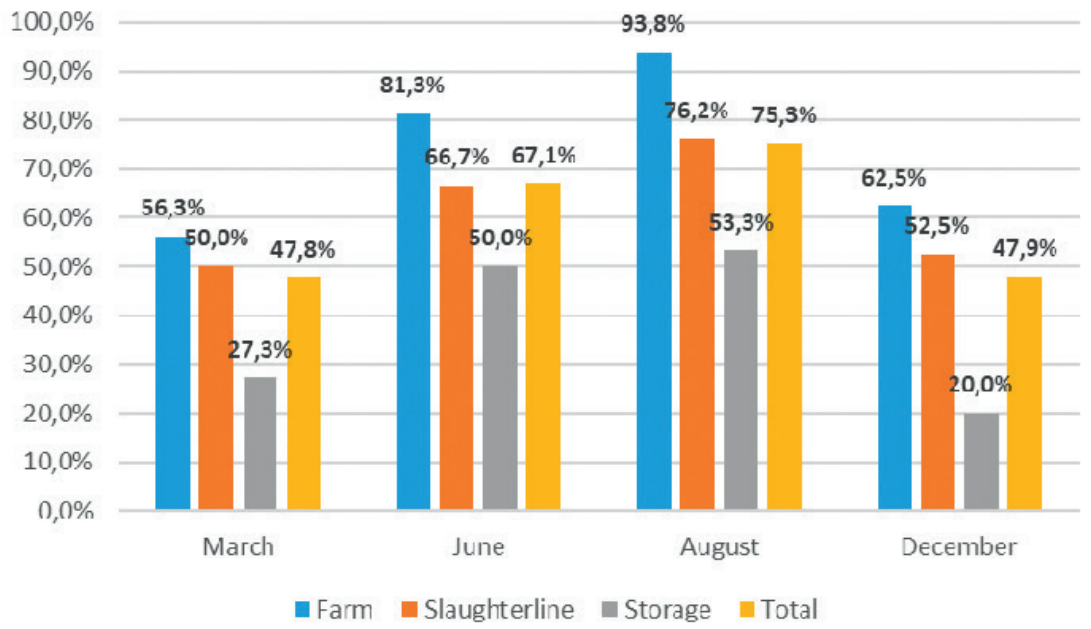

Figure 1. Seasonal prevalence of Campylobacter spp. along the broiler chain

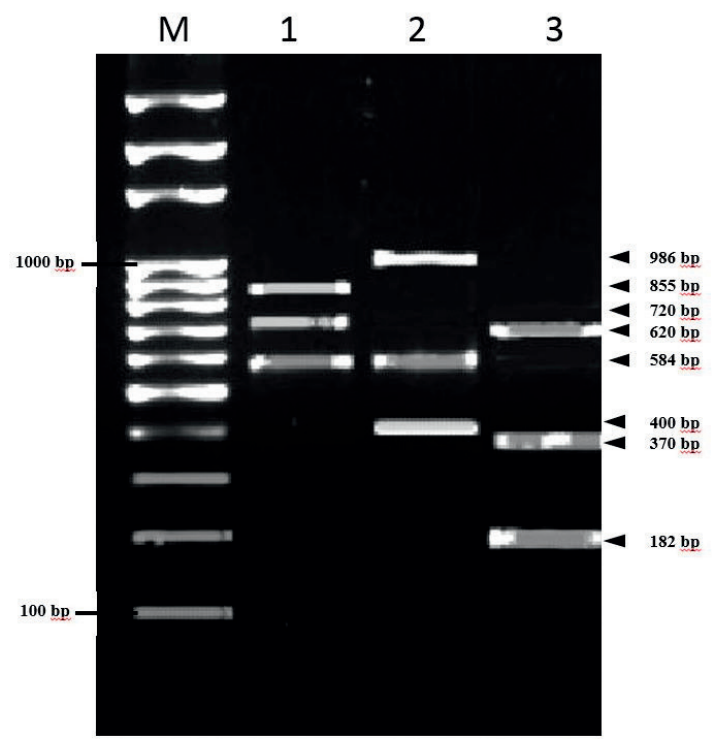

Figure 2. Visualization of PCR amplicons of virulence genes. Lane marked with M: 100-bp ladder; Lane 1: racR, dnaJ and flaA genes; Lane 2: $c a d F, r a c R$ and $c i a B$ genes; Lane 3: $c d t C, c d t A$ and $c d t B$ genes 
This study identified high prevalence of Campylobacter in carcasses (37.7\%), consisting mainly of isolates of C. jejuni $(22.6 \%)$, followed by C. $\operatorname{coli}(9.4 \%)$.

Seasonal variation in Campylobacter spp. prevalence

As previously mentioned, in several studies, Campylobacter spp. has shown a seasonal trend of higher prevalence in the warmer period of the year. In the current study (Fig. 1) we confirmed this trend with highest prevalence in the samples taken in August (75.3\%), followed by the June sampling period (67.1\%).

\section{Presence of virulence genes in C. jejuni}

Among the isolates, 111 were confirmed as $C$. jejuni by both the classical method and the multiplex PCR. Three of the isolates were dismissed because of technical issues with the template DNA purity. Therefore, 108 isolates were subjected to further analysis for the detection of virulence genes (Fig. 2; Table 4).

\section{Evaluation of the detected virulence patterns in} C. jejuni

In total, we detected 15 virulence patterns in the C. jejuni isolates. In $19.4 \%$ of the confirmed $C$. jejuni isolates, the analysis detected the profile No. 7. The second highest prevalence was detected for the profile No. 12 (in $13.9 \%$ of the isolates). The profile No. 1 (all of the virulence genes present except virB11) was confirmed only in 3 isolates $(2.8 \%)$ of $C$. jejuni (Table 5).

Table 4. Seasonal prevalence of virulence genes in C. jejuni

\begin{tabular}{|c|c|c|c|c|c|}
\hline \multirow[b]{2}{*}{ Virulence gene } & March & June & August & December & Average \\
\hline & \multicolumn{5}{|c|}{ n positive $(\%)$} \\
\hline$f a A$ & $8(40)$ & $17(58.6)$ & $20(48.8)$ & $9(50.0)$ & $54(50.0)$ \\
\hline rack & $5(25)$ & $8(27.6)$ & $11(26.8)$ & $6(33.3)$ & $30(27.8)$ \\
\hline virB11 & $0(0)$ & $0(0)$ & $0(0)$ & $0(0)$ & $0(0)$ \\
\hline $\operatorname{dna} J$ & $8(40)$ & $12(41.4)$ & $21(51.2)$ & 7 (38.9) & $48(44.4)$ \\
\hline wlaN & $2(10)$ & $5(17.2)$ & $7(17.1)$ & $1(5.6)$ & $15(13.9)$ \\
\hline$c a d F$ & $20(100)$ & $29(100)$ & $41(100)$ & $18(100)$ & $108(100)$ \\
\hline$c i a B$ & $20(100)$ & $29(100)$ & $41(100)$ & $18(100)$ & $108(100)$ \\
\hline$c d t A$ & $11(55)$ & $15(51.7)$ & $22(53.7)$ & $9(50.0)$ & $57(52.8)$ \\
\hline$c d t B$ & $11(55)$ & $15(51.7)$ & $22(53.7)$ & $9(50.0)$ & $57(52.8)$ \\
\hline$c d t C$ & $9(45)$ & $14(48.3)$ & $20(48.8)$ & $8(44.4)$ & $51(47.2)$ \\
\hline
\end{tabular}

Table 5. Virulence patterns of C. jejuni isolates

\begin{tabular}{|c|c|c|c|c|c|c|c|c|c|c|c|}
\hline \multirow{2}{*}{$\begin{array}{l}\text { No. } \\
1 .\end{array}$} & \multicolumn{9}{|c|}{ Virulence patterns } & \multirow{2}{*}{$\frac{\mathbf{n}}{3}$} & \multirow{2}{*}{$\begin{array}{l}\mathbf{\%} \\
2.8\end{array}$} \\
\hline & flaA & $c a d F$ & rack & dnaJ & $c i a B$ & wlaN & $c d t A$ & $c d t B$ & $c d t C$ & & \\
\hline 2. & flaA & $c a d F$ & rack & dnaJ & $c i a B$ & $c d t A$ & $c d t B$ & $c d t C$ & & 6 & 5.6 \\
\hline 3. & flaA & $c a d F$ & dnaJ & $c i a B$ & $c d t A$ & $c d t B$ & $c d t C$ & & & 3 & 2.8 \\
\hline 4. & flaA & $c a d F$ & $c i a B$ & $c d t A$ & $c d t B$ & & & & & 9 & 8.3 \\
\hline 5. & flaA & $c a d F$ & $\mathrm{rach}$ & $d n a J$ & $c i a B$ & $c d t C$ & & & & 6 & 5.6 \\
\hline 6. & flaA & $c a d F$ & dnaJ & $c i a B$ & wlaN & $c d t C$ & & & & 6 & 5.6 \\
\hline 7. & flaA & $c a d F$ & $c i a B$ & & & & & & & 21 & 19.4 \\
\hline 8. & $c a d F$ & $\mathrm{racR}$ & dnaJ & $c i a B$ & wlaN & $c d t A$ & $c d t B$ & $c d t C$ & & 3 & 2.8 \\
\hline 9. & $c a d F$ & $\mathrm{racR}$ & dnaJ & $c i a B$ & $c d t A$ & $c d t B$ & $c d t C$ & & & 12 & 11.1 \\
\hline 10. & $c a d F$ & $d n a J$ & $c i a B$ & wlaN & $c d t A$ & $c d t B$ & $c d t C$ & & & 3 & 2.8 \\
\hline 11. & $c a d F$ & dnaJ & $c i a B$ & $c d t A$ & $c d t B$ & $c d t C$ & & & & 3 & 2.8 \\
\hline 12. & $c a d F$ & $c i a B$ & $c d t A$ & $c d t B$ & & & & & & 15 & 13.9 \\
\hline 13. & $c a d F$ & dnaJ & $c i a B$ & $c d t C$ & & & & & & 3 & 2.8 \\
\hline 14. & $c a d F$ & $c i a B$ & $c d t C$ & & & & & & & 3 & 2.8 \\
\hline 15. & $c a d F$ & $c i a B$ & & & & & & & & 12 & 11.1 \\
\hline
\end{tabular}




\section{DISCUSSION}

In this study, Campylobacter spp. was present in all type of samples collected along the broiler meat production chain (cloacal swabs, caeca, and carcass swabs). The confirmed level of Campylobacter spp. on the broiler farm was very similar with the level confirmed in two studies performed on farms with comparable breeding conditions $(20,21)$.

This study also revealed high isolation rate of Campylobacter spp. (61.4\%) in the slaughterhouse (evisceration phase) in the cecum samples. Analysis of cecal samples showed a great variation in the isolation rate (region, age of the flock, seasonality, on farm pre-harvest measures, farm management) (22). In some studies, the isolation rate was in accordance with our results (23), but there are studies that report even higher isolation rate (24).

At the last point of sampling (cold storage), 37.7\% of the samples were positive. The point of concern is that $22.2 \%$ of the samples have shown to be positive for C. jejuni. This is important as from this point the poultry meat is dispatched to the consumers. If we follow the Campylobacter spp. presence along the production chain, we find reduced level but not eliminated level of contamination (25).

Our results have confirmed a well-defined seasonal pattern of flock colonization with Campylobacter spp. As observed by many authors, it is characterized with highest prevalence in summer or autumn $(26,27,28)$. The mechanism by which temperature affects Campylobacter colonization of broilers is probably linked with microbial survival, higher numbers of wildlife vectors, increased ventilation and fan speeds, insects, and rodents (29).

The pathogenicity of thermotolerant Campylobacter found in the broiler meat in addition to its isolation rate gives a clear picture of the public health risk. In this study we detected several of the virulence genes in $C$. jejuni isolates. Our results showed that $c a d F$ and $c i a B$ genes were detected in all of the confirmed strains (Table 5). Similar observations indicated that the $c a d F$ and $c i a B$ genes were present in the Campylobacter isolates from chicken carcasses and droppings $(19,30)$.

The analyses detected an isolation rate of $50 \%$ of the flaA gene which coordinate the motility and virulence $(31,32)$. Comparable levels of prevalence of this gene were detected in other studies $(33,34)$.

The frequency of $c d t$ genes $(52.8 \%, 52.8 \%$, and $47.2 \%$ ) that was observed in our C. jejuni isolates was close to the prevalence detected in studies by other authors $(35,36)$. This holotoxin (cdtABC) produced by campylobacters is a factor which has a great role in the development of the disease. All three toxin subunit genes $(c d t A, c d t B$, and $c d t C)$ are necessary for the cytotoxin expression (37).

The wlaN gene (prevalence of $13.9 \%$ ) is responsible for the metabolism of specific lipooligosaccharides (LOS) connected with disease sequelae such as Guillain-Barre syndrome $(38,39)$. Concerning the genes connected with adherence and colonization (40) the study results confirmed $44.4 \%$ prevalence of the $d n a J$ gene and lower prevalence of the racR gene (27.8\%). The virB11 gene, which is responsible for the expression of invasion (41), was not detected in the $C$. jejuni isolates.

The authors acknowledge that at the time of sample collection for the purpose of the current research, the country had a small-scale broiler production based on few farms and only one operating slaughterhouse imposing limitations of sample number.

\section{CONCLUSION}

This study confirmed high isolation rate of Campylobacter spp. in the broiler meat production chain. This statement is supported both at the farm and the slaughterhouse (evisceration phase and cold storage) in different type of analyzed samples. C. jejuni was more frequently isolated than $C$. coli at the three sampling points.

The Campylobacter isolation rate in the cold chamber samples was notable and relevant for public health consideration. C. jejuni isolates had varying virulence patterns $(n=15)$ and diverse pathogenic potential which are not always necessarily expressed in-vivo. The detected virulence genes and their patterns surely demonstrate the pathogenic potential of Campylobacter jejuni isolated across the broiler chain.

\section{CONFLICT OF INTEREST}

The authors declare that they have no potential conflict of interest with respect to the authorship and/or publication of this article.

\section{ACKNOWLEDGMENTS}

This research was supported by the Faculty of Veterinary Medicine - Skopje. The authors would like to express their gratitude to colleagues Prof. Kiril Krstevski and Prof. Igor Dzadzovski for their scientific advice and technical help. 


\section{AUTHORS' CONTRIBUTIONS}

LjA conceived and designed the study and wrote the manuscript. LjA, ZP, KB and MP performed the experiments. SM contributed to the final version. DJ gave critical revision. PS supervised the project and approved it for publishing.

\section{REFERENCES}

1. Kaakoush, N.O., Castaño-Rodríguez, N., Mitchell, H.M., Man, S.M. (2015). Global epidemiology of Campylobacter infection. Clin Microbiol Rev. 28(3): 687-720.

https://doi.org/10.1128/CMR.00006-15

2. Gillespie, I.A., O’Brien, S.J., Frost, J.A., Adak, G.K., Horby, P., Swan, A.V., Painter, M.J., Neal, K.R., Campylobacter Sentinel Surveillance Scheme Collaborators (2002). A case-case comparison of Campylobacter coli and Campylobacter jejuni infection: a tool for generating hypotheses. Emerg Inf Dis. 8(9): 937-942.

https://doi.org/10.3201/eid0809.010817

3. Tam, C.C., O’Brien, S.J., Adak, G.K., Meakins, S.M., Frost, J.A. (2003). Campylobacter coli - an important foodborne pathogen. J Infect. 47(1): 28-32.

https://doi.org/10.1016/s0163-4453(03)00042-2

4. Newell, D.G., Fearnley, C. (2003). Sources of Campylobacter colonization in broiler chickens. Appl Environ Microbiol. 69(8): 4343-4351. https://doi.org/10.1128/aem.69.8.4343-4351.2003

5. EFSA and ECDC (European Food Safety Authority and European Centre for Disease Prevention and Control), (2021).The European Union One Health 2019 zoonoses report. EFSA Journal 2021; 19(2):6406 https://doi.org/10.2903/j.efsa.2021.6406

6. Allos, B.M. (2001). Campylobacter jejuni infections: update on emerging issues and trends. Clin Infect Dis. 32(8): 1201-1206. https://doi.org/10.1086/319760

7. Cawthraw, S.A., Lind, L., Kaijser, B. Newell, D.G. (2000). Antibodies, directed towards Campylobacter jejuni antigens, in sera from poultry abattoir workers. Clin Exp Immunol. 122(1): 55-60. https://doi.org/10.1046/j.1365-2249.2000.01349.x

8. Deming, M.S., Tauxe, R.V., Blake, P.A., Dixon, S.E., Fowler, B.S., Jones, T.S., Lockamy, E.A., et al. (1987). Campylobacter enteritis at a university: transmission from eating chicken and from cats. Am J Epidemiol. 126(3): 526-534.

https://doi.org/10.1093/oxfordjournals.aje.a114685
9. Schorr, D., Schmid, H., Rieder, H.L., Baumgartner, A., Vorkauf, H., Burnens, A. (1994). Risk factors for Campylobacter enteritis in Switzerland. Zentralbl Hyg Umweltmed. 196(4): 327-337.

10. Studahl, A., Andersson, Y. (2000). Risk factors for indigenous campylobacter infection: a Swedish case-control study. Epidem Inf. 125(2): 269-275. https://doi.org/10.1017/s0950268899004562

11. McCarthy, N.D., Gillespie, I.A., Lawson, A.J., Richardson, J., Neal, K.R., Hawtin, P.R., Maiden, M.C., O'Brien, S.J. (2012). Molecular epidemiology of human Campylobacter jejuni shows association between seasonal and international patterns of disease. Epidemiol Infect. 140(12): 2247-2255. https://doi.org/10.1017/S0950268812000192

12. European Centre for Disease Prevention and Control. (2016). EU protocol for harmonised monitoring of antimicrobial resistance in human Salmonella and Campylobacter isolates.

13. Friedman, C.R., Neimann, J., Wegener,H.C., Tauxe, R.V. (2000). Epidemiology of Campylobacter jejuni infections in the United States and other industrialized nations. In: I. Nachamkin, M.J. Blaser (Eds.), Campylobacter (pp. 121-138). 2nd ed. Washington DC:ASM Press.

14. García-Sánchez, L., Melero, B., Rovira, J. (2018). Campylobacter in the food chain. Adv Food Nutr Res. 86, 215-252.

https://doi.org/10.1016/bs.afnr.2018.04.005

15. Casabonne, C., Gonzalez, A., Aquili, V., Subils, T., Balague, C. (2016). Prevalence of seven virulence genes of Campylobacter jejuni isolated from patients with diarrhea in Rosario, Argentina. Int J Infect. 3(4): e37727. doi:10.17795/iji-37727.

16. Bolton, D.J. (2015). Campylobacter virulence and survival factors. Food Microbiol. 48, 99-108. https://doi.org/10.1016/j.fm.2014.11.017

17. ISO 10272-1:2017 [Internet]. Microbiology of the food chain - Horizontal method for detection and enumeration of Campylobacter spp. - Part 1: Detection method.

https://www.iso.org/obp/ui/\#iso:std:iso:10272:-1:ed2:v1:en

18. Wang, G., Clark, C.G., Taylor, T.M., Pucknell, C., Barton, C., Price, L., Woodward, D.L., Rodgers, F.G. (2002). Colony multiplex PCR assay for identification and differentiation of Campylobacter jejuni, C. coli, C. lari, C. upsaliensis, and C. fetus subsp. fetus. J Clin Microbiol. 40(12): 4744-4747. https://doi.org/10.1128/jcm.40.12.4744-4747.2002 
19. Datta, S., Niwa, H., Itoh, K. (2003). Prevalence of 11 pathogenic genes of Campylobacter jejuni by PCR in strains isolated from humans, poultry meat and broiler and bovine faeces. J Med Microbiol. 52( $\mathrm{Pt} \mathrm{4):}$ 345-348.

https://doi.org/10.1099/jmm.0.05056-0

20. Saleha, A.A. (2002). Isolation and characterization of Campylobacter jejuni from broiler chickens in Malaysia. Int J Poult Sci. 1(4): 94-97.

https://doi.org/10.3923/ijps.2002.94.97

21. Schwan, P. (2010). Prevalence and antibiotic resistance of Campylobacter spp. in poultry and raw meat in the Can Tho Province, Vietnam. Degree Project. Swedish University of Agricultural Sciences.

22. EFSA Panel on Biological Hazards (BIOHAZ). (2011). Scientific opinion on Campylobacter in broiler meat production: control options and performance objectives and/or targets at different stages of the food chain. EFSA Journal 9(4): 2105. [141 pp.].

[Available online: www.efsa.europa.eu/efsajournal] doi:10.2903/j.efsa.2011.2105

23. Di Giannatale, E., Prencipe, V., Colangeli, P., Alessiani, A., Barco, L., Staffolani, M., Tagliabue, S., et al. (2010). Prevalence of thermotolerant Campylobacter in broiler flocks and broiler carcasses in Italy. Vet Ital. 46(4): 405-423.

24. Perez-Arnedo, I., Gonzalez-Fandos, E. (2019). Prevalence of Campylobacter spp. in poultry in three Spanish farms, a slaughterhouse and a further processing plant. Foods (Basel, Switzerland), 8(3): 111.

https://doi.org/10.3390/foods8030111

25. Zhu, J., Yao, B., Song, X., Wang, Y., Cui, S., Xu, Gong, P. (2017). Prevalence and quantification of Campylobacter contamination on raw chicken carcasses for retail sale in China. Food Cont. 75, 196-202.

https://doi.org/10.1016/j.foodcont.2016.12.007

26. Jorgensen, F., Ellis-Iversen, J., Rushton, S., Bull, S.A., Harris, S.A.,Bryan, S.J., Gonzalez, A., Humphrey, T.J. (2011). Influence of season and geography on Campylobacter jejuni and C. coli subtypes in housed broiler flocks reared in Great Britain. Appl Environ Microbiol. 77(11): 3741-3748.

https://doi.org/10.1128/AEM.02444-10

27. Rushton, S.P., Humphrey, T.J., Shirley, M.D., Bull, S., Jørgensen, F. (2009). Campylobacter in housed broiler chickens: a longitudinal study of risk factors. Epidemiol Infect. 137(8): 1099-1110. https://doi.org/10.1017/S095026880800188X
28. Nylen, G., Dunstan, F., Palmer, S. R., Andersson, Y., Bager, F., Cowden, J., Feierl, G., et al. (2002). The seasonal distribution of campylobacter infection in nine European countries and New Zealand. Epidemiol Infect. 128(3): 383-390. https://doi.org/10.1017/s09502688020068300

29. Patrick, M.E., Christiansen, L.E., Wainø, M., Ethelberg, S., Madsen, H., Wegener, H.C. (2004). Effects of climate on incidence of Campylobacter spp. in humans and prevalence in broiler flocks in Denmark. Appl Environ Microbiol. 70(12): 7474-7480. https://doi.org/10.1128/AEM.70.12.7474-7480.2004

30. Bang, D.D., Nielsen, E.M., Scheutz, F., Pedersen, K., Handberg, K., Madsen, M. (2003). PCR detection of seven virulence and toxin genes of Campylobacter jejuni and Campylobacter coli isolates from Danish pigs and cattle and cytolethal distending toxin production of the isolates. J Appl Microbiol. 94(6): 1003-1014.

https://doi.org/10.1046/j.1365-2672.2003.01926.x

31. Wieczorek, K., Osek, J. (2015). A five-year study on prevalence and antimicrobial resistance of Campylobacter from poultry carcasses in Poland. Food Microbiol. 49, 161-165.

https://doi.org/10.1016/j.fm.2015.02.006

32. Zhang, T., Luo, Q., Chen, Y., Li, T., Wen, G., Zhang, R., Luo, L., et al. (2016). Molecular epidemiology, virulence determinants and antimicrobial resistance of Campylobacter spreading in retail chicken meat in Central China. Gut Pathog. 8, 48.

https://doi.org/10.1186/s13099-016-0132-2

33. Laprade, N., Cloutier, M., Lapen, D.R., Topp, E., Wilkes, G., Villemur, R., Khan, I.U. (2016). Detection of virulence, antibiotic resistance and toxin (VAT) genes in Campylobacter species using newly developed multiplex PCR assays. J Microbiol Methods. 124, 41-47.

https://doi.org/10.1016/j.mimet.2016.03.009

34. Lapierre, L., Gatica, M.A., Riquelme, V., Vergara, C., Yañez, J.M., San Martín, B., Sáenz, L., et al. (2016). Characterization of antimicrobial susceptibility and its association with virulence genes related to adherence, invasion, and cytotoxicity in Campylobacter jejuni and Campylobacter coli isolates from animals, meat, and humans. Microb Drug Resist. (Larchmont, N.Y.). 22(5): 432-444. https://doi.org/10.1089/mdr.2015.0055

35. Ghorbanalizadgan, M., Bakhshi, B., Kazemnejadlili, A., Najar-Peerayeh, S., Nikmanesh, B. (2014). A molecular survey of Campylobacter jejuni and Campylobacter coli virulence and diversity. Iran Biomed J. 18(3): 158-164. https://doi.org/10.6091/ibj.1359.2014 
36. Nahar, N., Rashid, R.B. (2018). Genotypic analysis of the virulence and antibiotic resistance genes in Campylobacter species in silico. J Bioanal Biomed. $10,13-23$.

37. Koolman, L., Whyte, P., Burgess, C., Bolton, D. (2015). Distribution of virulence-associated genes in a selection of Campylobacter isolates. Foodborne Pathog Dis. 12(5): 424-432.

https://doi.org/10.1089/fpd.2014.1883

38. Gilbert, M., Brisson, J.R., Karwaski, M.F., Michniewicz, J., Cunningham, A.M., Wu, Y., Young, N.M., Wakarchuk, W.W. (2000). Biosynthesis of ganglioside mimics in Campylobacter jejuni OH4384. Identification of the glycosyltransferase genes, enzymatic synthesis of model compounds, and characterization of nanomole amounts by 600-mhz (1)h and (13)c NMR analysis. J Biol Chem. 275(6): 3896-3906.

https://doi.org/10.1074/jbc.275.6.3896
39. Rossler, E., Olivero, C., Soto, L.P., Frizzo, L.S., Zimmermann, J., Rosmini, M.R., Sequeira, G.J., et al. (2020). Prevalence, genotypic diversity and detection of virulence genes in thermotolerant Campylobacter at different stages of the poultry meat supply chain. Int J Food Microbiol. 326, 108641.

https://doi.org/10.1016/j.ijfoodmicro.2020.108641

40. Wysok, B., Wojtacka, J., Wiszniewska-Łaszczych, A., Szteyn, J. (2020). Antimicrobial resistance and virulence properties of Campylobacter spp. originating from domestic geese in Poland. Animals 10(4): 742.

https://doi.org/10.3390/ani10040742

41. Bacon, D.J., Alm, R.A., Burr, D.H., Hu, L., Kopecko, D.J., Ewing, C.P., Trust, T.J., Guerry, P. (2000). Involvement of a plasmid in virulence of Campylobacter jejuni 81-176. Infect Immun. 68(8): 4384-4390.

https://doi.org/10.1128/iai.68.8.4384-4390.2000 